\title{
パネルディスカッション
}

\section{臓器移植一移植医療の定着を図る一 司会者のことば}

司会小俣 政男

司会 和泉 徹

今, 我が国の蔵器移植は定着出来るか否かが 問われている．法体系のサポート下にこの医療 が発足した時，変節した経緯もあって医療サイ ドの力量や精神性を深く問われたことがある. しかし，今日までの具体的事例の積み重ねはこ の奬念を払拭しつつ，定着した医療への期待感 を膨らませている。この間の関係各位の努力に まず敬意を表したい，直接的課題は，むしろ移 植医療の原点であるドナー臓器確保に焦点が絞 られる。そこには一般社会における脳死概念の 受け入れと移植医療への参画という二つのス テップが横たわっている．これは本来的・具体 的課題であり，定着化への過程で世界が正面か ら取り組んだ問題でもある。今回のパネルでは この点を見据えた討論が展開された。

まず行政の立場から「臟器移植法の部平価と今 後」を厚生省 加藤誠実氏が論じた。臟器移植 の定着化や標準化をめぐる経済的・法律的展開
に注目が集まった，移植医療現場からはその領 域の第一人者からの生々しいメッセージが寄せ られた。腎臟移植・膵臓移植から高橋公太氏， 肝臓移植・小腸移植の田中紘一氏，心臓・心肺 移植の松田 暉氏, 肺移植の清水信義氏である. ドナー臟器の確保に尽力されている日本臓器移 植ネットワーク 寺岡 慧氏と, 日本救命医学 会 島崎修次氏は，意思表示カードに関連した ドナー情報と臓器提供施設における現状と問題 点にそれぞれ言及された。

いずれ，アジアの国々とドナー臓器提供につ いて協議する時が来るであろう。またそうであ らねばならない。穴の時までに今の気後れを引 きずるようでは我が国の医学や医療の質が問わ れよう。篠山会頭が企画したこのパネルディス カッションが実り多い具体的方策への第一歩に 結実することを願って止まない。 